\title{
PENERAPAN PENDEKATAN MODEL ELICITING ACTIVITIES (MEAs) DALAM PEMBELAJARAN MATEMATIKA UNTUK MENINGKATKAN KEMAMPUAN BERPIKIR KRITIS SISWA SMP
}

\author{
Junaidi (1), Taufiq (2) \\ 1,2 Program Studi Pendidikan Matematika FKIP Universitas Jabal Ghafur
}

\begin{abstract}
ABSTRAK
Untuk dapat mencapai tingkat ketuntasan siswa SMP Negeri 1 Simpang Tiga, guru perlu memperhatikan model yang digunakan dalam mengajar. Pendekatan Model Eliciting Activities (MEAs) dipilih menentukan tingkat keberhasilan siswa yaitu kemampuan berpikir kritis siswa. Dengan pembelajaran pendekatan Model Eliciting Activities (MEAs) siswa akan lebih mudah menemukan dan memahami konsep-konsep yang sulit apabila mereka saling mendiskusikan masalah-masalah dengan teman-temannya. Pendekatan yang digunakan adalah pendekatan kuantitatif, jenis penelitian kuasi eksperimen. Populasi dalam penelitian ini berjumlah 116 siswa dari empat kelas. Sampel dalam penelitian ini adalah kelas X-A sebagai kelas eksperimen dan X-B sebagai kelas kontrol dengan jumlah 57 siswa. Teknik pengumpulan data dilakukan melalui pemberian tes sedangkan teknik pengolahan dan analisis data diolah dengan menggunakan rumus uji-t. Hasil penelitian menunjukkan bahwa dari keseluruhan uraian diatas, maka dapat ditarik kesimpulan bahwa dari hasil pengolahan data Berdasarkan pengujian hipotesis dengan menggunakan uji-t dapat disimpulkan bahwa pembelajaran pendekatan Model Eliciting Activities (MEAs) dapat meningkatkan kemampuan berpikir kritis siswa dibandingkan dengan siswa yang diajarkan dengan metode konvensional.
\end{abstract}

Kata Kunci: Model Eliciting Activities (MEAs), Kemampuan Berpikir Kritis

\section{PENDAHULUAN}

Matematika merupakan mata pelajaran wajib bagi siswa pada jenjang pendidikan dasar dan menengah. Hal ini tertuang dalam Undang-Undang Nomor 20 Tahun 2003 Pasal 37 tentang Sistem Pendidikan Nasional. Matematika yang diberikan di sekolah memiliki peranan penting dalam upaya meningkatkan sumber daya manusia yang berkualitas khususnya di bidang teknologi informasi dan komunikasi yang sedang berkembang pesat saat ini. Penjelasan ini mengindikasikan bahwa matematika penting bagi masyarakat Indonesia khususnya pada dunia pendidikan. Matematika memegang peranan penting dalam pendidikan, baik sebagai objek langsung (fakta, keterampilan, konsep, prinsip) maupun objek tak langsung (bersikap kritis, logis, tekun, mampu memecahkan masalah). Oleh karena itu, berbagai kemampuan siswa dikembangkan melalui pembelajaran matematika seperti berpikir kritis, logis, cermat, kreatif dan inovatif selain itu dikembangkan pula kemampuan berhitung, kemampuan menalar dan kemampuan memahami konsep.

Pemahaman konsep melalui berpikir kritis matematika lebih bermakna jika dibangun oleh siswa sendiri. Pemberian konsep tanpa melibatkan siswa akan memberikan dampak pada kurangnya pengetahuan siswa dalam menemukan konsep sehingga siswa akan mudah lupa dengan konsep suatu materi dan kesulitan dalam menyelesaikan masalah yang berbeda karena kurangnya kemampuan berpikirsecara kritis yang baik dan benar.

Kemampuan berpikir kritis sangat dibutuhkan oleh siswa sebagai dasar dari materi yang berkelanjutan. Berpikirkritis merupakan salah satu kecakapan atau 
kemahiran matematika yang diharapkan dapat tercapai dalam belajar matematika yaitu dengan menunjukkan kemampuan berpikirkritis matematika yang dipelajarinya. Berpikir kritis sangat penting bagi siswa karena diguankan sebagai alat komunikasi dengan orang lain serta sebagai alat berpikirdalam belajar dan membaca. Tanpa adanya berpikirkritis maka belajar akan terhambat dan dengan adanya konsep dapat dijalankan pendidikan format.

Pembelajaran matematika yang berlangsung saat ini bersifat prosedural, siswa belum terbiasa untuk menyelesaikan soal yang bersifat nonrutin sehingga kemampuan berpikir tingkat tinggi seperti kemampuanberpikir kritis meraka belum terlatih. Padahal kemampuan ini diperlukan siswa untuk dapat mengembangkan, memahami konsep-konsep serta dapat menyelesaikan masalah.

Permasalahan-permasalahan yang dipaparkan di atas banyak ditemukan di sekolah-sekolah, salah satunya di SMP Negeri 1 Simpang Tiga. Informasi ini ditemukan saat studi pendahuluan yang dilaksanakan pada akhir tahun 2018/2019. Studi pendahuluan dilakukan dengan pemberian tes pemahaman konsep dan kemampuan pemecahan masalah siswa, observasi pembelajaran dan wawancara. Hasil tes terhadap kemampuan berpikir kritis pada materi relasi dan fungsi siswa menunjukkan bahwa rata-rata kemampuan berpikir kritis ssiswa 43,11 dengan skala 1100. Adapun rata-rata kemampuan berpikir kritis siswa 35,25 dengan skala 1-100.

Berdasarkan hasil observasi yang dilaksanakan di SMP Negeri 1 Simpang Tiga guru masih menekankan materi relasi dan fungsi dengan pemberian langsung. Guru memberikan materi dengan rumusrumus kemudian siswa diberikan soal latihan untuk dikerjakan bersama-sama dan sesekali guru meminta siswa untuk mengerjakan didepan kelas. Dalam pelaksanaan pembelajaran, guru menggunakan pembelajaran konvensional. Pembelajaran konvensional ini lebih terfokus pada guru dalam proses belajar mengajar matematika sehingga siswa kesulitan dalam menyelesaikan soal matematika dikarenakan kemampuan siswa hanya diingat dan dihafalkan tanpa melibatkan aktivitasnya siswa.

Dari hasil observasi terlihat siswa masih kesulitan dalam berpikir kritis. Berdasarkan pada hasil wawancara dengan siswa, siswa merasa bosan dan jenuh dengan pembelajaran matematika. Siswa menyatakan bahwa pembelajaran yang diberikan oleh guru terlalu cepat dan sedikit materi yang diperoleh siswa. Siswa merasa pengetahuan yang diperoleh masih kurang.

Alternatif pembelajaran yang diduga sesuai untuk menfasilitas pengembangan pemahaman konsep dan kemampuan berpikir kritis adalah pembelajaran matematika Model Eliciting Activities (MEAs). Pembelajaran Model Eliciting Activities (MEAs) adalah pembelajarn matematika untuk memahami, menjelaskan, mengkomunikasikan konsepkonsep matematika yang terkandung dalam suatu sajian permasalahan melalui permodelan matematika.

Wina Sanjaya,

mendefinisikan bahwa ada dua macam pendekatan dalam pembelajaran, yaitu pendekatan yang berpusat pada guru (teacher-centered approaches) dan pendekatan yang berpusat pada siswa (student-centered approaches).

Pendekatan Model-Eliciting Activities (MEAs) didasarkan pada kehidupan nyata siswa, maksudnya dalam pembelajaran Model-Eliciting Activities (MEAs) permasalahan yang diberikan kepada siswa merupakan masalah yang ada di kehidupan nyata. Dengan adanya permasalahan tersebut siswa dapat lebih mudah memahami masalah dan menerjemahkan masalah dengan baik. 
Pendekatan pembelajaran ModelEliciting Activities (MEAs) merupakan pembelajaran yang didasarkan pada kehidupan nyata siswa, bekerja dalam kelompok kecil, dan menyajikan sebuah model matematis sebagai solusi (Suningsih, 2015:32).

Pendekatan Model-Eliciting Activities (MEAs) merupakan pendekatan yang didasarkan pada masalah realistis, bekerja dalam kelompok kecil, dan menyajikan sebuah model untuk membantu siswa membangun pemecahan masalah dan membuat siswa menerapkan pemahaman konsep matematika yang telah dipelajarinya. Iiterasi pemecahan masalah yang paling penting dari sebuah Model-Eliciting Activities (MEAs) adalah untuk mengemukakan, menguji, dan meninjau kembali model yang akan memecahkan suatu permasalahan. Jadi berdasarkan uraian diatas, dapat disimpulkan bahwa pendekatan Model-Eliciting Activities (MEAs) adalah pendekatan yang didasarkan pada masalah untuk mengetahui proses berpikir siswa dalam memecahkan masalah melaui konsepkonsep didalamnya dengan suatu pemodelan matematika.

\section{Model-Eliciting Activities (MEAs)} secara ideal disusun untuk membantu siswa dalam memecahkan masalah yang berkaitan dengan kehidupan nyata sehingga siswa memiliki konstruksi matematika yang kuat. MEAs membantu perkembangan pemikiran siswa karena siswa membuat model mereka sendiri untuk memecahkan masalahmasalah matematika. Siswa tidak perlu berlama-lama mencari satu jawaban yang mungkin hanya diketahui oleh gurunya. Untuk memperkenalkan MEAs, guru tidak mencontohkan proses algoritma untuk menyelesaikan permasalahan seperti yang dilakukan dalam langkah-langkah pembelajaran biasa. Dalam MEAs siswa didorong untuk belajar mandiri, menemukan metode-metode dan model-model yang dapat memecahkan permasalalahan.

Model-Eliciting Activities (MEAs) siswa menghasilkan alat konseptual (rumus) yang berisi penggambaran eksplisit atau sistem penjelasan yang berfungsi sebagai model dimana siswa memberitahu aspekaspek penting bagaimana siswa tersebut menginterpretasi situasi pemecahan masalah.

Pendekatan pembelajaran Model Eliciting Activities (MEAs) merupakan pembelajaran yang didasarkan pada kehidupan nyata siswa, bekerja dalam kelompok kecil, dan menyajikan sebuah model matematis sebagai solusi (Suningsih, 2015:32).

Model-Eliciting Activities (MEAs) membantu perkembangan pemikiran siswa karena siswa membuat model mereka sendiri untuk memecahkan masalahmasalah matematika. Model Eliciting Activities (MEAs) juga mendorong keaktifan siswa dalam proses pembelajaran dan juga mengeksplorasi kemampuan hasil berpikir siswa dalam memahami konsep dengan mengkomunikasikan pemikiran matematika melalui pemodelan dan kemampuan memecahkan masalah. Berdasarkan uraian di atas, pendekatan Model Eliciting Activities (MEAs) adalah pendekatan yang berpusat pada siswa dimana kegiatan yang dilakukan dimulai dengan penyajian masalah dari kehidupan nyata yang ada di sekitar siswa, kemudian dari permasalahan dibentuk suatu model, selanjutnya siswa berupaya mencari penyelesaian dari model tersebut sebagai solusi.

Secara lebih khusus, Model-Eliciting Activities (MEAs) diterapkan dalam beberapa langkah, yaitu:

1. Guru memberikan sebuah artikel yang memuat permasalahan yang berhubungan dengan konteks pelajaran bagi siswa

2. Siswa merespon masalah-masalah yang terdapat pada artikel tersebut

3. Guru membaca kembali permasalahan 
bersama dengan siswa dan memastikan setiap kelompok mengerti yang ditanyakan.

4. Siswa membuat model matematika dari permasalahan tersebut secara berkelompok

5. Setelah siswa menyelesaikan permasalahan tersebut, siswa mempresentasikan hasil pekerjaan mereka di depan kelas.

Model Eliciting Activities (MEAs) dapat diterapkan dalam beberapa langkah, yaitu:

1. Guru membaca sebuah artikel yang mengembangkan konteks siswa

2. Siswa siap dengan pertanyaan berdasarkan artikel tersebut

3. Guru membacakan pernyataan masalah bersama siswa dan memastikan bahwa setiap kelompok mengerti apa yang sedang ditanyakan

4. Siswa berusaha untuk menyelesaikan masalah tersebut (Suningsih, 2015:33).

Pengertian berpikirkritis merupakan sebuah aktivitas yang selalu dilakukan manusia, bahkan ketika sedang tertidur. Bagi otak, berpikirdan menyelesaikan masalah merupakan pekerjaan paling penting, bahkan dengan kemampuan yang tidak terbatas. Berpikir kritis adalah pemikiran yang masuk akal dan reflektif yang berfokus untuk memutuskan apa yang mesti dipercaya atau dilakukan (Alec Fisher, 2008:4). Dalam penalaran dibutuhkan kemampuan berpikir kritis atau dengan kata lain kemampuan berpikir kritis merupakan bagian dari penalaran.

Menurut Sardiman (2006:45), berpikirmerupakan aktivitas mental untuk dapat merumuskan pengertian, mensintesis, dan menarik kesimpulan. Ngalim Purwanto (2007: 43) berpendapat bahwa berpikiradalah satu keaktifan pribadi manusia yang mengakibatkan penemuan terarah kepada suatu tujuan. Manusia berpikir untuk menemukan pemahaman/pengertian yang dikehendakinya. Santrock (2011: 357) juga mengemukakan pendapatnya bahwa berpikir adalah memanipulasi atau mengelola dan mentransformasi informasi dalam memori. Berpikirsering dilakukan untuk membentuk konsep, bernalar dan bepikir secara kritis, membuat keputusan, berpikir kreatif, dan memecahkan masalah.

Jika berpikirmerupakan bagian dari kegiatan yang selalu dilakukan otak untuk mengorganisasi informasi guna mencapai suatu tujuan, maka berpikir kritis merupakan bagian dari kegiatan berpikir yang juga dilakukan otak. Menurut Santrock (2011: 359), pemikiran kritis adalah pemikiran reflektif dan produktif, serta melibatkan evaluasi bukti. Jensen (2011: 195) berpendapat bahwa berpikir kritis berarti proses mental yang efektif dan handal, digunakan dalam mengejar pengetahuan yang relevan dan benar tentang dunia.

Gagasannya mengenai kemampuan berpikir kritis, yaitu kegiatan menganalisis ide atau gagasan ke arah yang lebih spesifik, membedakannya secara tajam, memilih, mengidentifikasi, mengkaji dan mengembangkannya ke arah yang lebih sempurna (Cece Wijaya, 2010: 72).

Berdasarkan beberapa pendapat ahli tersebut, dapat diambil kesimpulan mengenai pengertian kemampuan berpikir kritis yaitu sebuah kemampuan yang dimiliki setiap orang untuk menganalisis ide atau gagasan ke arah yang lebih spesifik untuk mengejar pengetahuan yang relevan tentang dunia dengan melibatkan evaluasi bukti. Kemampuan berpikirkritis sangat diperlukan untuk menganalisis suatu permasalahan hingga pada tahap pencarian solusi untuk menyelesaikan permasalahan tersebut.

Berpikir kritis adalah berpikir dengan baik dan merenungkan atau mengkaji tentang proses berpikir orang lain. Sekolah harus mengajarkan cara berpikir yang benar pada anak- anak. Kemudian beliau mendefenisikan berpikir kritis (critical thinking), yaitu: "Aktif, gigih, dan pertimbangan yang cermat mengenai sebuah 
keyakinan atau bentuk pengetahuan apapun yang diterima dipandang dari berbagai sudut alasan yang mendukung dan menyimpulkannya (Hendra Surya, 2011:129).

Orang-orang yang memiliki kemampuan berpikir kritis tidak hanya mengenal sebuah jawaban. Mereka akan mencoba mengembangkan kemungkinankemungkinan jawaban lain berdasarkan analisis dan informasi yang telah didapat dari suatu permasalahan. Berpikirkritis berarti melakukan proses penalaran terhadap suatu masalah sampai pada tahap kompleks tentang "mengapa" dan "bagaimana" proses pemecahannya.

Dari beberapa pendapat para ahli tentang definisi berpikirkritis di atas dapat disimpulkan bahwa berpikir kritis (critical thinking) adalah proses mental untuk menganalisis atau mengevaluasi informasi. Untuk memahami informasi secara mendalam dapat membentuk sebuah keyakinan kebenaran informasi yang didapat atau pendapat yang disampaikan. Proses aktif menunjukkan keinginan atau motivasi untuk menemukan jawaban dan pencapaian pemahaman. Dengan berpikir kritis, maka pemikir kritis menelaah proses berpikir orang lain untuk mengetahui proses berpikir yang digunakan sudah benar (masuk akal atau tidak). Secara tersirat, pemikiran kritis mengevaluasi pemikiran yang tersirat dari apa yang mereka dengar, baca dan meneliti proses berpikir diri sendiri saat menulis, memecahkan masalah, membuat keputusan atau mengembangkan sebuah proyek.

Terdapat delapan indikator berpikir kritis, yaitu:

1) Kegiatan merumuskan pertanyaan.

2) Membatasi permasalahan.

3) Menguji data-data.

4) Menganalisis berbagai pendapat dan bias.

5) Menghindari pertimbangan yang sangat emosional.

6) Menghindari

penyederhanaan berlebihan.

7) Mempertimbangkan berbagai interpretasi.

8) Mentoleransi ambiguitas (Hendra Surya, 2011:54).

Definisi berpikir kritis adalah berpikir secara beralasan dan reflektif dengan menekankan pembuatan keputusan tentang apayang harus dipercayai atau dilakukan. Oleh karena itu, indikator kemampuan berpikirkritis diturunkan dari aktivitas kritis siswa meliputi:

1) Mencari pernyataan yang jelas dari pertanyaan.

2) Mencari alasan.

3) Berusaha mengetahui infomasi dengan baik.

4) Memakai sumber yang memiliki kredibilitas dan menyebutkannya.

5) Memerhatikan situasi dan kondisi secara keseluruhan.

6) Berusaha tetap relevan dengan ide utama.

7) Mengingat kepentingan yang asli dan mendasar.

8) Mencari alternatif.

9) Bersikap dan berpikir terbuka.

10) Mengambil posisi ketika ada bukti yang cukup untuk melakukan sesuatu.

11) Mencari penjelasan sebanyak mungkin.

12) Bersikap secara sistematis dan teratur dengan bagian dari keseluruhan masalah (Ennis, 2013:14).

Untuk menjadi pemikir kritis yang baik dibutuhkan kesadaran dan keterampilan memaksimalkan kerja otak melalui langkah-langkah berpikir kritis yang baik, sehingga kerangka berpikir dan cara berpikir tersusun dengan pola yang baik. Walau memang belum ada rumusan langkah-langkah berpikirkritis yang dapat dijadikan tolak ukur atau parameter yang baku. Sebab, berpikir kritis bisa sangat sulit untuk diukur karena berpikirkritis sangat sulit untuk diukur karena berpikirkritis 
adalah proses yang sedang berlangsung bukan hasil yang mudah dikenali.

\section{METODE}

Penelitian ini dilakukan dengan menggunakan pendekatan kuantitatif. Pendekatan kuantitatif adalah pendekatan yang dapat diukur dengan angka dan jumlah. Metode penelitian yang digunakan adalah metode eksperimen semu (quasi experimental). Dalam metode penelitian ini, peneliti ikut serta dalam penelitian dengan mengajar matematika di sekolah tersebut dengan menggunakan pendekatan Model Eliciting Activities (MEAs) untuk meningkatkan kemampuan berpikirkrisis siswa SMP, kemudian membandingkan hasil tes pemahaman matematika siswa pada kelas eksperimen dengan menggunakan pendekatan Model Eliciting Activities (MEAs) dan pada kelas kontrol diajarkan dengan model pembelajaran ceramah.

Populasi merupakan seluruh data yang menjadi perhatian dalam suatu ruang lingkup dan waktu yang ditentukan. Adapun populasi dalam penelitian ini adalah seluruh siswa Kelas VIII SMP Negeri Simpang Tiga yang terdiri dari 4 kelas dengan jumlah siswa 116 siswa.

Sampel adalah sebagian dari populasi yang memiliki karakteristik yang sama dengan populasi. Sampel penelitian ini diambil menggunakan teknik Cluster Random Sampling. Teknik pengambilan sampel ini digunakan karena obyek yang diteliti sangat luas sehingga pengambilan sampel dilakukan secara kelompok bukan secara individu, sehingga semua kelompok memiliki kesempatan yang sama untuk digunakan sebagai sampel. Dari teknik sampling tersebut didapatkan sampel Kelas $\mathrm{VIII}_{\mathrm{A}}$ yang proses belajarnya menggunakan pendekatan Model-Eliciting Activities (MEAs), sedangkan kelas VIII $_{B}$ sebagai kelas kontrol yang penyajian materinya menggunakan metode ceramah/ konvensional.

Untuk mendapatkan data dalam penelitian ini peneliti mengajarkan materi soal-soal tentang relasi dan fungsi dan lebih memfokuskan kepada kemampuan berpikir kritis pelajaran matematika siswa supaya siswa termotivasi.

Teknik pengumpulan data yang digunakan dalam penelitian ini adalah tes. Tes adalah seperangkat rangsangan (stimulasi) yang diberikan kepada siswa dengan maksud untuk mendapat jawaban yang dapat dijadikan dasar bagi penetapan skor angka. Dalam penelitian ini evaluasi hasil belajar dilakukan melalui post tes. Tes yang di berikan dalam bentuk assay, yang jumlah soal di sesuaikan dengan tujuan pembelajaran.

Analisis data tes kemampuan berpikir kritis siswa diperlukan untuk mengetahui ada tidaknya kemampuan untuk menentukan pencapaian ketuntasan belajar siswa pada kelas eksperimen dan kelas kontrol. Setelah semua data terkumpul, langkah selanjutnya adalah melakukan pengujian normalitas dan homogenitas terhadap semua data tersebut. Kemudian dihitung uji beda menggunakan uji studen $t$.

\section{HASIL DAN PEMBAHASAN}

Berdasarkan hasil uji normalitas yang telah dilakukan sebelumnya didapat kesimpulan bahwa skor gain ternormalisasi kelas Model Eliciting Activities (MEAs) dan kelas konvensional berdistribusi normal. Sedangkan untuk uji homogenitas menunjukkan bahwa varians skor gain ternormalisasi kemampuan berpikir kritis kedua kelompok homogen. Sehingga untuk membuktikan bahwa skor gain ternormalisasi kemampuan berpikir kritis siswa kelas Model Eliciting Activities (MEAs) berbeda dengan kelas konvensional dilakukan uji perbedaan rataan skor gain ternormalisasi dengan menggunakan uji-t.

Tabel 1.

Data Hasil Uji Perbedaan Rataan Skor Gain Ternormalisasi

\begin{tabular}{|c|c|c|c|}
\hline \multicolumn{3}{|c|}{ t-test for Equality of Means } & \multirow{2}{*}{ Kesimpulan } \\
\cline { 1 - 3 } $\mathrm{t}$ & $D f$ & Sig. (2-tailed) & \\
\hline 7,909 & 55 & 0,000 & $\mathrm{H}_{0}$ Ditolak \\
\hline
\end{tabular}


Tabel diatas diperoleh $\mathrm{t}_{\text {hitung }}=7,909$ untuk $\alpha=0,05$ dengan $d f=55$, nilai $\mathrm{t}_{\text {tabel }}=2,02$, maka $\mathrm{t}_{\text {hitung }}$ berada di daerah penolakan $\mathrm{H}_{0}$, atau nilai signifikan $0,000<\alpha=0,05$ sehingga $\mathrm{H}_{0}$ ditolak yang artinya terdapat perbedaan yang signifikan antara peningkatan kemampuan berpikir kritis siswa yang mendapat Model Eliciting Activities (MEAs). Dengan demikian peningkatan kemampuan berpikir kritis siswa yang mendapat Model Eliciting Activities (MEAs) lebih baik daripada siswa yang mendapatkan pembelajaran konvensional.

Model-Eliciting Activities (MEAs) membantu perkembangan pemikiran siswa karena siswa membuat model mereka sendiri untuk memecahkan masalah-masalah matematika. Model Eliciting Activities (MEAs) juga mendorong keaktifan siswa dalam proses pembelajaran dan juga mengeksplorasi kemampuan hasil berpikir siswa dalam memahami konsep dengan mengkomunikasikan pemikiran matematika melalui pemodelan dan kemampuan memecahkan masalah. Berdasarkan uraian di atas, pendekatan Model Eliciting Activities (MEAs) adalah pendekatan yang berpusat pada siswa dimana kegiatan yang dilakukan dimulai dengan penyajian masalah dari kehidupan nyata yang ada di sekitar siswa, kemudian dari permasalahan dibentuk suatu model, selanjutnya siswa berupaya mencari penyelesaian dari model tersebut sebagai solusi.

\section{Simpulan}

Dari keseluruhan uraian diatas, maka dapat ditarik kesimpulan bahwa dari hasil pengolahan yaitu Pembelajaran matematika melalui model penerapan pendekatan Model Eliciting Activities (MEAs) dapat meningkatkan kemampuan berpikir kritis siswa .

Berdasarkan pengujian hipotesis dengan menggunakan uji-t diperoleh nilai $\mathrm{t}_{\text {hitung }}=3,49$ dengan signifikan $\mathrm{t}_{\text {tabel }}=1,68$ maka hipotesisnya adalah terima $\mathrm{H}_{\mathrm{a}}$ dan tolak $\mathrm{H}_{\mathrm{o}}$. Dengan demikian dapat disimpulkan bahwa terdapat perbedaan kemampuan berpikir kritis siswa kelas eksprimen dengan siswa kelas kontrol.

Berdasarkan hasil penelitian yang di lakukan oleh peneliti di SMP Negeri 1 Simpang Tiga dengan penerapan Model Eliciting Activities (MEAs) dapat meningkatkan kemampuan berpikir kritis siswa SMP Negeri 1 Simpang Tiga.

\section{DAFTAR PUSTAKA}

A, Cece. Wijaya. 2010. Kemampuan Dasar Guru Dalam Proses Belajar Mengajar. Bandung : PT. Remaja Rosda karya.

Alec Fisher. 2009. Berpikir Kritis Sebuah Pengantar. Terj. Benyamin Hadinata. Jakarta: Erlangga.

Ari Suningsih, 2015. Pembelajaran Garis Lurus dengan MEAs dan TAI Ditinjau dari Gaya Kognitif', Jurnal e-DuMath, 1:1.

Ennis. 2013. Berpikir Kritis Sebuah Pengantar. Jakarta: Erlangga.

Hendra Surya, 2011. Strategi Jitu Mencapai Kesuksesan Belajar. Jakarta: Kompas. Media.

Jensen, T. \& Sandström, J. 2011, "Stakeholder Theory and Globalization: The Challenges of Power and Responsibility". Article (PDF Available) in Organization.

Santrock, 2011. Psikologi Pendidikan. Jakarta: Selemba Empat.

Sardiman. 2006. Interaksi dan Motivasi Belajar-Mengajar. Jakarta :Raja Grafindo Persada.

Wina Sanjaya, 2011. Penelitian Tindakan Kelas. Jakarta: Kencana Prena. 